\title{
Moms are better nurses than dads: gender biased self-facilitation in a dioecious Juniperus tree
}

\author{
Montesinos, Daniel*; Verdú, Miguel \& García-Fayos, Patricio \\ Centro de Investigaciones sobre Desertificación (CSIC-UV-GV), Apt. Oficial, ES-46470 Albal, València, Spain; \\ *Corresponding author; daniel.montesinos@uv.es
}

\begin{abstract}
Questions: Can gender of nurse plants affect regeneration patterns and spatial population structure? Is there a seedseedling conflict in the regeneration process? What factors are responsible for the clumped spatial population structure observed for adult trees?

Location: Mediterranean cold semi-arid high mountains in Spain.

Methods: The spatial pattern of adult Juniperus thurifera trees was studied by means of Ripley's $K$-analysis. $\chi^{2}$ analyses were used to test for natural seedling frequency in each of three main microhabitats: (1) under female and (2) male tree canopies and (3) in open interspaces. The observed pattern was explained experimentally by studying seed and seedling survival for two years. Survival probabilities were calculated across life stages for each of three main microhabitats.

Results: Adult $J$. thurifera trees were aggregated in space. Most seedlings were found underneath female J. thurifera trees. Experimental studies demonstrated that from seed dispersal to seedling survival all life stages showed the same positive or negative trend within a given microhabitat, indicating stage coupling and no seed-seedling conflicts. Attraction of frugivorous birds by reproductive female junipers and improvement of environmental conditions beneath tree canopies were the main factors responsible for the variation in seedling density among microhabitats; highest underneath female trees and lowest in open interspaces.

Conclusions: In dioecious species, the gender of nurse plants can significantly determine the spatial population structure. In $J$. thurifera forests, facilitation beneath female trees occurs among all life stages without any sign of seed-seedling conflict. The most critical factors shaping the spatial population structure were directed seed dispersal and environmental amelioration beneath female conspecific trees.
\end{abstract}

Keywords: Juniperus thurifera; Seed dispersal; Seed-seedling conflict; Spatial discordance; Spatial population structure; Stage coupling.

Nomenclature: Castroviejo et al. (1986).

\section{Introduction}

Facilitation is a common phenomenon under stressful environmental conditions (e.g. Callaway 1995; Callaway et al. 2002). In Mediterranean ecosystems summer drought is the primary environmental stress factor and the main cause of juvenile plant mortality (e.g. Herrera et al. 1994; García-Fayos \& Verdú 1998; Traveset et al. 2003; Gulías et al. 2004). In these arid environments, nurse plants improve physical conditions and enhance seed germination and seedling survival (Verdú \& GarcíaFayos 1996a; Castro et al. 2004; Gómez-Aparicio et al. 2004) and offer protection from herbivores (García \& Obeso 2003).

Facilitation can be species-specific (Callaway 1998), varying in intensity within a species because of phenologically plastic morphology (Callaway et al. 1991, 2003). However, plant ecologists have rarely compared genders within one plant species in search for gender-specific facilitative interactions (but see Verdú \& García-Fayos 1996a, 2003; Verdú et al. 2004). Variation in survival between different microhabitats may yield different survival outcomes, resulting in spatial discordance (Jordano \& Herrera 1995; Schupp 1995).

Frugivorous birds feed on fleshy fruits of female plants, resulting in disproportionate amounts of seeds being dispersed just below the canopies (Holthuijzen \& Sharik 1985; Herrera 1988; Herrera et al. 1994; Nanami et al. 1999; Calviño-Cancela 2002). Post-dispersal seed predators may also attack hosts with different intensities depending on the type of microhabitat (Hulme 1997; Tomita et al. 2002; Hollander \& Vander Wall 2004; Gulías et al. 2004). When seeds escape predation by being buried in the soil, their longevity and germination are likely to be influenced by the environmental properties of the soil surface, which vary among microhabitats (Rotundo \& Aguiar 2005 and references therein). After seed germination, shading provided by nurse plants protects the seedlings from desiccation by decreasing soil temperatures during summer and enhancing the soil water balance (Callaway 1995; Verdú \& García-Fayos 1996a, 2003). Organic matter and total nitrogen content are frequently higher beneath shrubs than in open spaces 
(Callaway 1995; Joy \& Young 2002; Verdú \& GarcíaFayos 2003; Verdú et al. 2004). Furthermore, females of fleshy-fruited species tend to increase nutrient availability beneath their canopies due to fruit deposition and accumulation of disperser's faeces (Verdú \& García-Fayos 1996a, 2003).

Previous studies have demonstrated that the spatial population structure is affected by many factors, which may differ among life stages. For each microhabitat the sign and intensity of selection may be coupled or uncoupled across life stages. When coupled, all life stages respond similarly, either positively or negatively, to the microhabitat matrix. Uncoupling occurs when the survival probability from a particular demographic stage deviates from that from previous stages (Jordano \& Herrera 1995). These relationships have also been referred to as concordant and discordant, respectively (Schupp 1995).

In this work we describe the heterogeneous spatial population structure of the dioecious Juniperus thurifera and use experimental methods to study the processes that affect early life stages in three different microhabitats: beneath male trees, beneath female trees and in open interspaces. Furthermore, we calculate survival probabilities across life stages for each of the three main microhabitats and compare these to the observed spatial pattern to test the robustness of our estimations. Specific questions addressed in this work are: 1 . Are adults and seedlings of $J$. thurifera distributed randomly in space? 2. Are regeneration rates higher in some microhabitats than in others? 3. Do all life stages show the same trend among microhabitats (stage coupling or concordance)? 4. Is water stress an equally strong limiting factor for seedling establishment in all microhabitats?

\section{Methods}

\section{Study species}

Juniperus thurifera is a dioecious long-lived tree with a Tertiary relict distribution throughout the western Mediterranean Basin, usually dominating in high-mountain low-density forests. Trees are typically $5-10 \mathrm{~m}$ high and often live for centuries (Bertaudière et al. 1999). Female trees bear fleshy cones with $1-7$ seeds (mean $=3.5, N=$ 2000). Seed viability and germination rate are extremely low (Ceballos \& Ruiz de la Torre 1979; Melero \& GarcíaFayos 2001). Seeds germinate from cones without bird gut-passage (García-Fayos unpubl. data). At least $55 \%$ of the cones are dispersed by medium-sized passerine birds of the genus Turdus (Santos \& Tellería 1994; Santos et al. 1999) which, when overwintering in J. thurifera forests, are almost monophagous on J. thurifera cones and their abundance and activity increases with increasing juniper crop size (Zamora 1990; Jordano 1993; Santos et al. 1999; García \& Ortiz-Pulido 2004). Juniper cones represent only a minor part of the diet of carnivores and ungulates (Santos et al. 1999); although these mammals may travel and disperse seeds long distances, they play a quantitatively inferior role compared to thrushes (Santos et al. 1999).

\section{Study site}

The study was performed at La Puebla de San Miguel, Ademuz, in the province of Valencia, southeastern Spain. The study site is situated at $1500 \mathrm{~m}$ a.s.l. and is dominated by J. thurifera. Natural vegetation covers less than $40 \%$ of the rocky soil surface while the rest of the open spaces had herbaceous ephemeral vegetation, lichens and scattered Thymus and Genista plant individuals. The soils are limestone soils $<30 \mathrm{~cm}$ deep, although cracks in the rocks allow roots to reach greater depths (Verdú et al. 2004). The climate is Mediterranean, with cold winters (freezing period of more than 120 days/year) and warm and dry summers. Mean annual total precipitation is 486 $\mathrm{mm}$ with October as the wettest month $(59 \mathrm{~mm})$ and July as the driest $(27 \mathrm{~mm})$. Annual mean temperature is 13 ${ }^{\circ} \mathrm{C}$, with August the warmest month (mean $22.8^{\circ} \mathrm{C}$ ) and January the coldest (mean $4.8^{\circ} \mathrm{C}$ ). The study area was used for agriculture, timber and extensive livestock grazing for centuries. Narrow valleys were tilled for rye and barley until land abandonment in 1960 (Rodrigo 1999). In the last decades, social and economic changes have led to a return to forest by abandonment of traditional land uses (Lasanta 1996), although livestock grazing is still noticeable (D. Montesinos pers. obs.).

\section{Natural population structure}

All adult individuals ( $>2 \mathrm{~m}$ high) in one randomly chosen hectare square were located on a grid and coordinates (to the nearest $\mathrm{m}$ of trunk centres) were recorded. Spatial population structure was assessed by Ripley's $K(r)$ test. Any individual more than $2 \mathrm{~m}$ high was considered an adult tree and classified as male, female or non-reproductive. The analysis was done with the freeware SPPA 2.0 designed by Dr. P. Haase (http://haasep.homepage.t-online.de/). Ripley's $K(r)$ compares the observed number of plants within a distance $r$ of an arbitrary plant with the expected number of plants within that distance for randomly distributed plants. Observed densities above the critical interval for a random distribution indicates significant clumping while the converse indicates significant overdispersion. To facilitate interpretation, the derived Ripley's $K$ sampling statistic $[\sqrt{ }(K(r) / p)-r]$ was used, which has zero 
expectation for all $r$ when the pattern is random.

In the spring of 2004 we intensively sampled seedlings and saplings in a square with total surface area of 2 ha which included the 1 ha sampled for the study of adult population spatial structure. For practical reasons the sampled area was subdivided into subplots $30 \mathrm{~m}$ wide and $10 \mathrm{~m}$ long. In this 2-ha square we recorded the proportion occupied by of each three microhabitats along 66 linear transects, each $30 \mathrm{~m}$ long and $10 \mathrm{~m}$ apart. Microhabitats were: beneath male trees ( $18 \%$ of the soil surface), beneath female trees ( $10 \%$ of the soil surface) and open interspaces ( $71 \%$ of the soil surface), for simplicity referred to as male tree, female tree and open, respectively. All seedlings (plants with needle-like leaves only, up to about 3 years old) and saplings (non-reproductive plants less than 2 $\mathrm{m}$ in height, with cypress-like leaves) were counted and the microhabitat in which they were located was typified by inspection. Microhabitat proportions were used for the calculation of the expected probabilities of seedling occurrence in $\chi^{2}$ tests. Analyses were made with the statistical software R, version 2.3.0 (Ihaka \& Gentleman 1996 www.r-project.org). This type of Chi-square test compares and calculates the expected probabilities according to an a priori given proportion (i.e. relative proportion of microhabitats). We tested if seedlings and saplings were found more often under adults than in open spaces and under females more often than under male adults. Adults without signs of recent reproduction, even without remains of fallen cones under their canopies, were classified as non-reproductive. Cones are resinous and seeds have a thick seed coat. Hence, cone decomposition is slow and females that had reproduced recently were characterised by presence of cone remains and/or seeds around their stems (D. Montesinos pers. obs.). We assumed that individuals classified as non-reproductive had not been a seed source for years, and that these were influencing their immediate surroundings the same way males do. Consequently, they were grouped with males for this analysis.

\section{Microhabitat characterization}

In the summer of 2004 we randomly selected across the 2-ha square 15 points in each of the three microhabitats to record: photosynthetically active radiation (PAR) at ground level, soil bulk density, soil compaction and three chemical soil properties (organic matter, total nitrogen and available phosphorus). PAR was measured on a totally clear day at noon with a quantum sensor (Skye Instruments, Llandrindod-Wells, UK) as the mean of three measurements. Soil compaction was measured with a penetrometer (Eijkelkamp type IB, Giesbeek, NL) with conic head (measurement range 5 to 400 Newton. $\mathrm{cm}^{-2}$ ) as the mean of 10 measurements.
Data were log-transformed to achieve a homogeneous variance distribution and approximate normal distribution of errors. Soil bulk density was calculated as the dry weight of the soil contained in cylindrical cores 5 $\mathrm{cm}$ deep by $5 \mathrm{~cm}$ diameter, divided by the volume of that cylinder. The samples used for soil bulk density determination were also used for soil chemical properties, using the Walkley, Kjeldahl and Olsen procedures for quantification of organic matter, total $\mathrm{N}$ and available P, respectively (Page 1982). Generalized Linear Models with Gaussian distribution of errors were fit to the data to test differences among microhabitats, when necessary with Tamhane post-hoc analyses (Zar 1996). The SPSS statistical software Version 11.0 (Norusis 2002) was used.

\section{Seed dispersal}

During the peak of the dispersal period (December 16, 2003; January 14, 2004 and February 4, 2004), we searched for fresh bird faeces and regurgitations containing $J$. thurifera seeds on a random linear transects one $m$ wide with total area of $1196 \mathrm{~m}^{2}$, distributed across the 2-ha square. Only fresh excrements (i.e. from the same day) were considered. For each $\mathrm{m}^{2}$ along each transect microhabitat type was visually classified, and faeces were collected and visually classified by dispersal agent. In the laboratory, seeds were hand extracted and counted. According to our hypothesis, birds direct dispersal towards trees as a result of regurgitation and defecation under the perches where they rest, and towards females, as birds are attracted to trees that bear fleshy fruits (Herrera 1988; Herrera et al. 1994; Verdú \& García-Fayos 1996a; Verdú \& García-Fayos 2003). Accordingly, the spatial distribution of dispersed seeds was expected to be consistent among years (Nathan \& Muller-Landau 2000; Hampe 2004). $\chi^{2}$ tests for observed vs expected numbers of observations (the latter calculated from proportion of area occupied by each microhabitat) were performed to assess differences in seed dispersal between open spaces and under tree canopies, and between female and male (including non-reproductive) tree canopies.

\section{Post-dispersal seed predation}

Sets of five seeds were offered to ants and mice. Seeds offered to ants $(N=400)$ were placed randomly across the studied population inside Petri dishes with a 5-mm wide hole and a small stone over the lid in order to protect them from removal by rain or wind. Seeds offered to mice $(N=400)$ were glued with Loctite ${ }^{\circledR}$ to a plastic mesh and nailed to the soil. Twenty dishes and 20 meshes were randomly placed under different male and female trees, 40 dishes and 40 meshes in open space 
which occupies more than $60 \%$ of the area. Seed removal was recorded monthly from 12 December 2002 to 30 September 2003. Because many units were destroyed by livestock, we also placed sets of 5 dishes and 5 meshes under each of male and female trees and 10 dishes and 10 meshes in open spaces inside fenced areas. Recorded was made from 28 April 2003 to 30 September 2003. There were no statistically significant differences between fenced and non-fenced treatments and all data were pooled for statistical analysis. Generalized Linear Models with Poisson distributions of errors (McCullagh $\&$ Nelder 1989) were fit to data for each experiment (each predator) to test if seed removal and predation differed among microhabitats.

\section{Soil seed bank}

Four mesh bags, each with 250 seeds, were buried in the soil at $5 \mathrm{~cm}$ depth in October 2002. Mean seed viability at that time, visually assessed by judgement if seeds were filled or not, was determined from a sub-sample of 100 seeds to be $5 \%$. Seeds were extracted from the soil in April 2005 and viability was again checked. Our visual assessment of viability was compared with the standard tetrazolium test for viability and no difference between the two procedures was found (D. Montesinos, unpublished results). Seed germination normally occurs in the field 16-18 months after seed dispersal. We therefore assumed viability after 30 months to provide a reliable estimate for the relative size of the seed bank of $J$. thurifera at the second germination period after seed dispersal.

\section{Seedling emergence}

Sets (female and male trees: 10 sets each; open: 19 sets) of 30 viable seeds (non-viable seeds, i.e. that floated in water, were discarded), collected in the field at the study site in October 2002, were sown at random locations in the field in November 2002 at $1 \mathrm{~cm}$ depth under $50 \mathrm{~cm} \times 50 \mathrm{~cm}$ wire mesh cages to prevent seed predation by mice. Mean seed viability after seed selection by flotation was $35 \%(N=100)$. In each microhabitat half of the cages (nine in open microsites) received a watering treatment consisting of 5 litres of water every month from March to October, except in July and August, the months with the greatest water deficit, in which they received 5 litres twice per month. This treatment the annual water supply by $40 \%$. Final seedling emergence was recorded in July 2004. GLMs with Poisson distributions of errors were used to test if microhabitat and/or watering treatment had an effect on seedling emergence.

\section{Seedling survival}

In early April 2003, 15-month old seedlings were manually planted at a density of 10 seedlings per $10 \mathrm{~m}^{2}$ plot. Each seedling was planted $1 \mathrm{~m}$ from the next nearest seedling. Plots were fenced to exclude herbivory. Sample sizes were: open (20 plots, $N=200$ seedlings), male trees ( 10 plots, $N=100)$ and female trees $(10$ plots, $N=$ 100). Half the plots received 1 liter water per seedling per month until October, but in July and August 1 liter twice a month. Water was poured immediately below the seedlings. If we consider a seedling's root influence area to be $25 \mathrm{~cm} \times 25 \mathrm{~cm}$, each watering event corresponded to addition of $16 \mathrm{~mm}$ of precipitation. This treatment, repeated 10 times per year, was equivalent to an increase in precipitation of ca. $30 \%$.

An additional set of 20 plots ( 10 plots in the open, five under males and five under females; $N=200$ seedlings) were exposed to herbivory by sheep and goats. None of these seedlings received a watering treatment. On 6 November 2003 and on 22 September 2004 survival was recorded. During the experiment four plots from which herbivores were excluded, were lost. Data were analysed with GLM with binomial distributions of errors. First we analysed the effect of herbivory on seedling survival. As no significant effect was found, data from seedlings exposed to herbivores and from exclusion areas were pooled and re-analysed with a GLM for the survival of seedlings over the first and the second summer, depending on the watering treatment and the microhabitat. Microhabitat was considered as an ordered factor following the expected pattern (open $<$ male trees $<$ female trees), as seedling survival was expected to be higher beneath trees where environmental conditions were expected to be more favourable, especially beneath female trees where soil nutrient concentrations were expected to be higher than in the open due to enrichment by cone deposition (Verdú \& García-Fayos 1996a, 2003 and references therein).

\section{Transition probabilities}

Transition probabilities (indicating survival probabilities) were calculated for each microhabitat for the following life-stage transitions: (1) proportion of seed rain in each microhabitat; (2) survival to post-dispersal seed predation; (3) seedling emergence (4) seedling survival to the first year and (5) seedling survival to the second year. Seedling emergence was extremely low, zero in some treatments. To avoid null values in some columns of the transition matrix, we assigned a single mean seedling emergence value to all columns since no statistical differences were detected among microhabitats. This mean value was similar to other germination studies with $J$. 
thurifera seeds in natural conditions (P. García-Fayos unpubl. data). The product of all of individual transition probabilities is the probability with which dispersed seeds arrived at a specific microhabitat and developed into established saplings two years later.

To assess the reliability of the cumulative transition values, we set up simple simulations for each microhabitat, each rerun 1000 times, using values for each transition randomly generated from a normal distribution, with means and standard deviations derived from the mean transition values for the microhabitat. Negative values on the left tail of distributions were meaningless and hence truncated to zero. A confidence interval of 95\% was then established for each of the six sets of 1000 values each, and significant differences between microhabitats were established to the 0.05 significance level.

- Independent validation of the precision of results was made by comparing expected values obtained from transition probabilities with available data of crop size from three years in the study site. To do so, we assumed that all factors were equal among years, and applied transition probabilities to crop sizes for years 2000 to 2002 (2000=37 500 cones/ha; 2001=163900 cones/ha; $2002=141900$ cones/ha). In year 2003 crop size was 9740 cones per ha. In that year, we directly measured an average of 0.78 dispersed seeds $/ \mathrm{m}^{2}$. Projecting that proportion to crop size from previous years we estimated dispersed seed densities of 3.18 seeds $/ \mathrm{m}^{2}, 15.35$ seeds/ $\mathrm{m}^{2}$, and 13.29 seeds $/ \mathrm{m}^{2}$ for years 2000, 2001 and 2002, respectively. We applied those values to the transition rates with the following considerations: for the year 2000, we assumed that seedling survival from the third year was the same as for the second year; for the year 2002, transition probabilities were calculated only up to first year seedling survival. Since seeds germinate 16 months after dispersal and seedlings remain in the needleleaved state up to 3 years we could estimate the expected density of seedlings up to 3 years old. We summed final estimations of seedling densities from the three cohorts and obtained the expected seedling densities. Then, we compared these densities with the results of observed seedling densities.

Fig. 1. Ripley's $K$ compares the observed number of plants within a distance of an arbitrary plant with the expected number of plants within that distance in a random distribution. Here, Ripley's $K$ function $[\sqrt{ }(K(r) / \pi)-r]$ is plotted for which the zero line represents the expected density of plants for each distance $r$ (in $\mathrm{m}$ ) in a random spatial distribution. Dashed lines represent the $95 \%$ critical interval for a random distribution. The solid line shows the observed distribution of the studied population. Positive values indicate plant aggregation and negative values overdispersion.

\section{Results}

\section{Natural population structure}

Adult $J$. thurifera density in the study area was 269 trees/ha. Adult population structure showed significant aggregation, notably for spatial distances below $4 \mathrm{~m}$ (Fig. 1).

Seedling $(N=161)$ and sapling $(N=587)$ occurrences were strongly dependent on microhabitat (Fig. 2). Seedlings were found beneath trees more than twice as often as in open interspaces $\left(\chi^{2}=31.3, d f=1, p<0.001\right)$ and threefold more often beneath female trees than beneath male trees $\left(\chi^{2}=20.9, d f=1, p<0.001\right)$. A similar trend was found for saplings both under tree canopies $v s$. open $\left(\chi^{2}=22.2, d f=1, p<0.001\right)$ and beneath female vs. male trees $\left(\chi^{2}=12.7, d f=1, p<0.001\right)$.

\section{Microhabitat characterization}

Open interspaces had significantly greater PAR than microhabitats underneath trees and differed significantly also in all other variables, presenting less favourable soil conditions for plant growth (Table 1). The only measured variable for which significant differences between male and female trees was observed was soil nitrogen concentration (63\% higher under female than under male trees).

\section{Seed dispersal}

We extracted a total of 532 seeds from 283 units of faeces. A mean of 0.06 seeds $/ \mathrm{m}^{2}$ were dispersed to open habitats; 0.55 seeds $/ \mathrm{m}^{2}$ to underneath male trees and 1.74 seeds $/ \mathrm{m}^{2}$ to underneath female trees. Significantly more seeds were dispersed under trees than into open $\left(\chi^{2}=\right.$ $712.2, d f=1, p<0.001)$, and seed dispersal to female trees was significantly greater than dispersal to male trees $\left(\chi^{2}=137.4, d f=1, p<0.001\right)$.

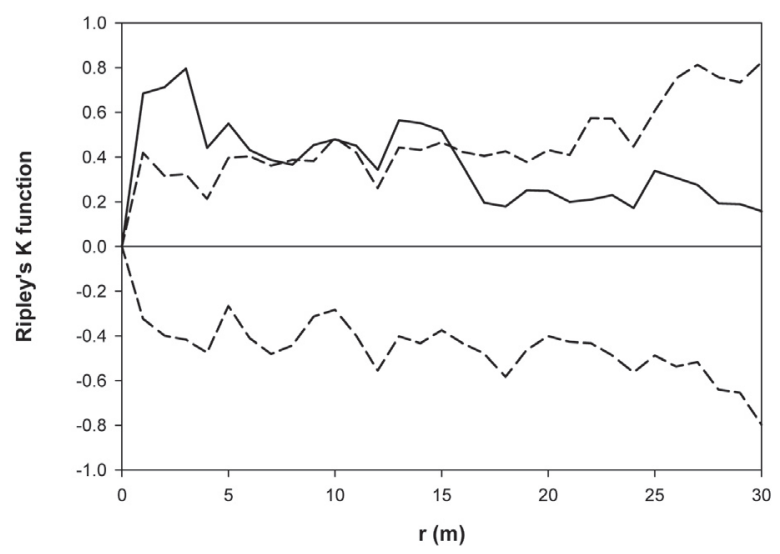




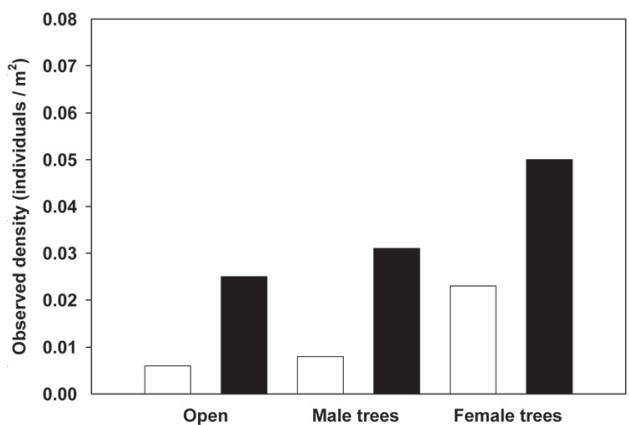

Fig. 2. White bars represent observed seedling densities and black bars observed sapling densities. Both are significantly higher below trees than in open and higher below female trees than anywhere else.

\section{Post-dispersal seed predation}

Final seed predation differed among microhabitats (Table $2 ; \chi_{77}^{2}=10.8, p<0.001$ ). Significantly more seeds were harvested by mice in open spaces than under trees $(p<0.001)$. Seed coat remnants eaten by mice were often found around the experimental sets, evidencing effective seed predation. Seed predation by mice did not differ between male and female trees $(p=0.815)$. Seed removal by ants did not differ among the studied microhabitats $\left(\chi_{63}^{2}=21.41, p=0.351\right)$.

\section{Soil seed bank and seedling emergence}

Initial seed viability just after seed collection was $5 \%$. Only three out of 1000 buried seeds $(0.3 \%)$ were still viable 30 months after collection.

Seedlings emerged 16 months after sowing (spring 2004). Only eight seedlings emerged out of the 1170 sown seeds: five under non watered females; one under a watered female and two in non watered open spaces. GLM with Poisson distribution of errors did not show any effect of microhabitats or watering on seedling emergence.

\section{Seedling survival}

Seedling survival of planted seedlings $(N=600)$ varied among watering treatments, microhabitats and years (Fig. 3). Herbivore exclusion neither affected seedling survival the first year $(42 \pm 23 \%$ vs. $29 \pm 8 \%$ in excluded vs. non-excluded plots respectively; estimate $=-0.29 \pm 0.55, t=-0.53, p=0.599)$ nor the second year $(94 \pm 12$ vs. $84 \pm 35$ in excluded vs. non-excluded plots respectively; estimate $=-0.35 \pm 0.98, t=-0.36, p$ $=0.724)$. Watering had a significantly positive effect on seedling survival the first year (estimate $=2.04 \pm$ $0.41, t=4.99, p<0.001$ ), increasing survival almost four fold. In contrast, differences were not significant the second year (estimate $=6.75 \pm 1065.51, t=0.01$, $p=0.995)$. Seedlings survival was significantly higher under female than under male trees, and higher under male trees than in the open (linear contrast $1.80 \pm 0.57$, $t=3.14, p<0.005)$. Differences were not significant in the second year (linear contrast $0.91 \pm 0.77 t=1.81, p=$ $0.248)$. No significant interaction between microhabitat and watering treatments was observed (linear contrasts: first year: $0.03 \pm 0.72, t=0.04, p=0.966$; second year: $0.51 \pm 1.03, t=0.49, p=0.628$ ).

\section{Transition probabilities}

Transition (survival) probabilities between subsequent life stages revealed that seeds were dispersed more often, and that seeds and seedlings survived more often, under female than under male trees, and under male trees more often than in open spaces (Table 3). Cumulative survival probabilities were enhanced by watering and were higher underneath female trees than in other microhabitats. Confidence intervals (95\%) showed two independent subgroups: open microhabitats (open-no watering: $1.6 \cdot 10^{-8}$ to $7.7 \cdot 10^{-6}$; open-watering: $4.4 \cdot 10^{-7}$ to $5.8 \cdot 10^{-5}$ ); males overlapping between the two subgroups (under male-no watering: $9 \cdot 10^{-6}$ to $8 \cdot 10^{-4}$; under malewatering: $4.3 \cdot 10^{-5}$ to $1.6 \cdot 10^{-3}$ ) and females on a second subgroup (under female-no watering: $4.3 \cdot 10^{-5}$ to $3.3 \cdot 10^{-3}$; under female-watering: $3.4 \cdot 10^{-4}$ to $5.4 \cdot 10^{-3}$ ).

Table 1. Open spaces had greater PAR but less favorable soil properties than sites under tree canopies. Mean values \pm standard deviations are given for each environment. $F$-values for the GLM are given $(d f=2)$; different letters indicate significant differences among microhabitats according to the post-hoc analyses $(p \leq 0.05)$.

\begin{tabular}{|c|c|c|c|c|}
\hline & Open & Male trees & Female trees & $F$ \\
\hline $\operatorname{PAR}\left(\mu \mathrm{Mol} / \mathrm{m}^{2} / \mathrm{sec}\right)$ & $1481.6 \pm 404.9^{\mathrm{a}}$ & $56.2 \pm 17.5^{\mathrm{b}}$ & $190.4 \pm 385.1^{\mathrm{b}}$ & $89.2 * * *$ \\
\hline Soil compaction $\left(\mathrm{N} / \mathrm{cm}^{2}\right)$ & $27.30 \pm 20.36^{\mathrm{a}}$ & $0.65 \pm 1.29^{\mathrm{b}}$ & $1.53 \pm 3.06^{\mathrm{b}}$ & $24.2 * * *$ \\
\hline Soil bulk density $\left(\mathrm{g} / \mathrm{cm}^{3}\right)$ & $0.62 \pm 0.09^{\mathrm{a}}$ & $0.34 \pm 0.17^{\mathrm{b}}$ & $0.34 \pm 0.16^{\mathrm{b}}$ & $16.0 * * *$ \\
\hline Organic matter $(\%)$ & $13.41 \pm 5.04^{\mathrm{a}}$ & $37.90 \pm 14.29^{b}$ & $35.54 \pm 16.08^{b}$ & $16.7 * * *$ \\
\hline $\mathrm{P}_{2} \mathrm{O}_{5}(\mathrm{mg} / 100 \mathrm{~g}$ soil $)$ & $3.11 \pm 1.36^{\mathrm{a}}$ & $9.22 \pm 3.82^{b}$ & $7.72 \pm 3.28^{b}$ & $16.8 * * *$ \\
\hline $\mathrm{N}_{\mathrm{T}}(\%)$ & $0.81 \pm 0.27^{\mathrm{a}}$ & $1.47 \pm 0.47^{b}$ & $2.34 \pm 0.87^{\mathrm{c}}$ & $25.3 * * *$ \\
\hline$* * * p \leq 0.001$ & & & & \\
\hline
\end{tabular}




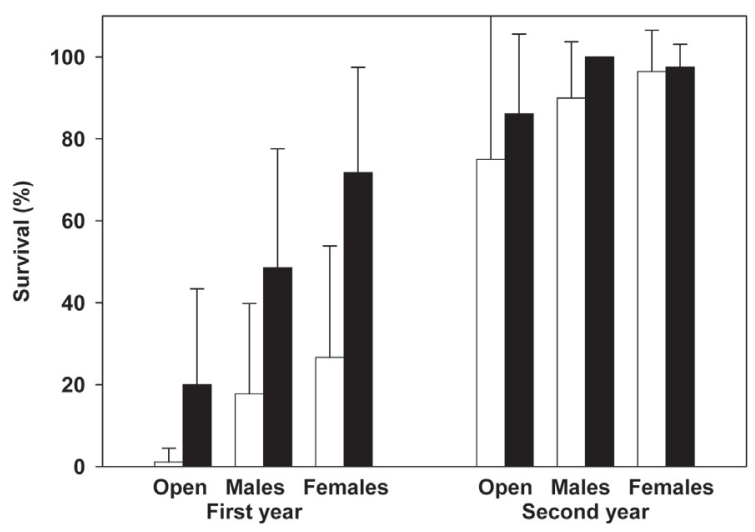

Fig. 3. Mean percentages of seedling survival \pm SD are given. White bars represent controls and black bars watered seedlings. Watering regime and environment significantly affected seedling survival during the first year, but not during the second.

When compared, predicted and observed seedling densities were closely similar (Fig. 2 and Fig. 4), although observed seedling density in open was higher than expected. A one-sample $t$-test was made between the observed and expected (not watered) values of seedling density. There were no statistically significant differences between observed and expected seedling densities under male $(t=1.16, d f=64, p=0.250)$ and female microhabitats $(t=-0.04, d f=64, p=0.964)$. Expected and observed values for open areas were significantly different $(t=5.28, d f=64, p<0.001)$.

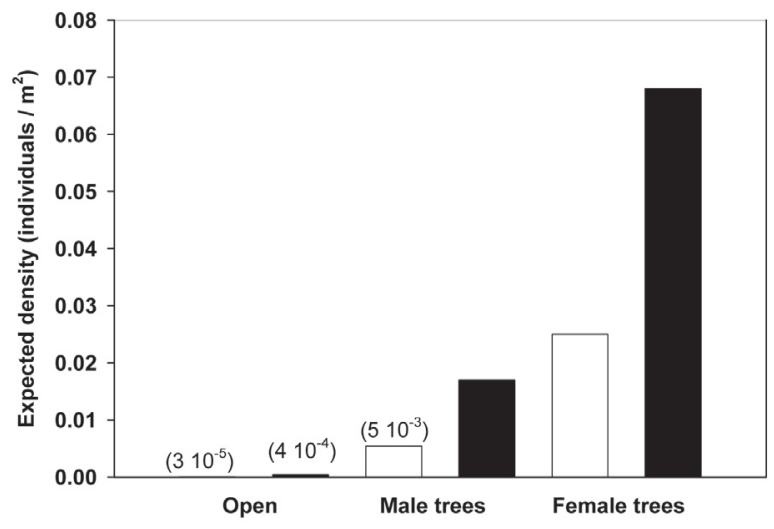

Fig. 4. Expected seedling density (seedlings $/ \mathrm{m}^{2}$ ) in each environment and watering treatment based on probabilities from Table 3 and considering crop size from years 2000, 2001 and 2002. White bars represent expected seedling density under natural conditions and black bars when watered.

\section{Discussion}

All life stages from seed dispersal to seedling establishment are favoured underneath $J$. thurifera female conspecifics, resulting in a clumped adult population structure. As expected, and in agreement with previous studies with J. sabina (Verdú \& García-Fayos 2003), birds dispersed significantly more seeds beneath females than beneath males and there more than in open spaces.

Seed removal by ants was similar among microhabitats (18\%), in agreement with other studies (Rey et al. 2002 and references therein). Predation by the omnivorous and highly efficient mice (Hansson 1985; Santos \& Tellería 1991) did, on the other hand, result in removal of $66 \%$ of

Table 2. Percent of mean seed removal $( \pm$ SD) by mice and ants for each microhabitat. Different letters indicate significant differences $(p<0.05)$ among microhabitats.

\begin{tabular}{lcccc}
\hline & Open & Male trees & Female trees & Total \\
\hline Mice & $83.00 \pm 18.42 \%^{\mathrm{a}}$ & $50.00 \pm 37.10 \%^{\mathrm{b}}$ & $48.18 \pm 26.66 \%^{\mathrm{b}}$ & $66.00 \pm 30.75 \%$ \\
Ants & $17.58 \pm 24.87 \%^{\mathrm{a}}$ & $6.67 \pm 9.76 \%^{\mathrm{a}}$ & $26.67 \pm 31.44 \%^{\mathrm{a}}$ & $17.58 \pm 25.18 \%$ \\
\hline
\end{tabular}

Table 3. Transition probabilities between subsequent life stages of Juniperus thurifera (and cumulative values in brackets), showing a clear pattern of spatial discordance and a strong degree of stage coupling.

\begin{tabular}{|c|c|c|c|c|c|c|}
\hline & \multicolumn{2}{|c|}{ Open } & \multicolumn{2}{|c|}{ Male trees } & \multicolumn{2}{|c|}{ Female trees } \\
\hline Seed rain & \multicolumn{2}{|c|}{0.02} & \multicolumn{2}{|c|}{0.24} & \multicolumn{2}{|c|}{0.74} \\
\hline Post-disp. seed pred. & \multicolumn{2}{|c|}{$\begin{array}{c}0.47(0.01) \\
\downarrow\end{array}$} & \multicolumn{2}{|c|}{$\begin{array}{c}0.70(0.16) \\
\downarrow\end{array}$} & \multicolumn{2}{|c|}{$\begin{array}{c}0.62(0.45) \\
\downarrow\end{array}$} \\
\hline \multirow[t]{2}{*}{ Seedling emergence } & \multicolumn{2}{|c|}{$6.8 \cdot 10^{-3}\left(8.0 \cdot 10^{-5}\right)$} & \multicolumn{2}{|c|}{$6.8 \cdot 10^{-3}\left(1.1 \cdot 10^{-3}\right)$} & \multicolumn{2}{|c|}{$6.8 \cdot 10^{-3}\left(3.1 \cdot 10^{-3}\right)$} \\
\hline & $\swarrow$ & $\searrow$ & $\swarrow$ & $y$ & $\swarrow$ & $y$ \\
\hline Seedling surv. $1^{\text {st }} \mathrm{yr}$. & $\begin{array}{c}0.02\left(1.3 \cdot 10^{-6}\right) \\
\downarrow\end{array}$ & $\begin{array}{c}0.20\left(1.6 \cdot 10^{-5}\right) \\
\downarrow\end{array}$ & $\begin{array}{c}0.18\left(2.0 \cdot 10^{-4}\right) \\
\downarrow\end{array}$ & $\begin{array}{c}0.49\left(5.4 \cdot 10^{-4}\right) \\
\downarrow\end{array}$ & $\begin{array}{c}0.27\left(8.2 \cdot 10^{-4}\right) \\
\downarrow\end{array}$ & $\begin{array}{c}0.72\left(2.2 \cdot 10^{-3}\right) \\
\downarrow\end{array}$ \\
\hline Seedling surv. $2^{\text {nd }} \mathrm{yr}$. & $0.75\left(0.9 \cdot 10^{-6}\right)$ & $0.86\left(1.4 \cdot 10^{-5}\right)$ & $0.90\left(1.8 \cdot 10^{-4}\right)$ & $1.00\left(5.4 \cdot 10^{-4}\right)$ & $0.96\left(7.9 \cdot 10^{-4}\right)$ & $0.97\left(2.2 \cdot 10^{-3}\right)$ \\
\hline & No watering & Watering & No watering & Watering & No watering & Watering \\
\hline
\end{tabular}


the available $J$. thurifera seeds, proportionally more in open spaces than under tree canopies. This contrasts the results of a majority of studies (e.g. Alcántara et al. 2000; Rey et al. 2002 and references therein) in which seed predation is often more intense under parent plants than elsewhere. The behaviour of granivores is affected by many factors, among other interactions between altitude, temperature, microhabitat, predation risk, dependence of stable refuges and food accessibility (Diaz 1994; Verdú \& García-Fayos 1996b; Rey et al. 2002). A full understanding of factors affecting post-dispersal seed predation of $J$. thurifera seeds requires further research.

Seed viability was negligible after the first germination period $(0.3 \%)$, in accordance with other studies of J. thurifera (Orozco Bayo 1999). Accordingly only current seed rain appears to play a role in J. thurifera regeneration.

Because of the very low seedling emergence in our experiments, no significant differences among treatments were found. On the other hand, experimentally planted seedlings survived more often under female than under male trees, and more often under male trees than in the open. Statistical analysis of the spatial distribution pattern of naturally occurring seedlings supported these experimental results. Seedling mortality was highest during the hot and dry summer months, as in other Mediterranean plants (Herrera et al. 1994; García-Fayos \& Verdú 1998; Traveset et al. 2003) and other Juniperus species (Jackson \& Van Auken 1997; Joy \& Young 2002). Watering experiments greatly improved seedling survival and differences in seedling survival among microhabitats were reduced when seedlings were regularly watered. Furthermore, watering increased seedling survival proportionally more in the most unfavourable microhabitat. These results support the hypothesis that improvement of environmental conditions will attenuate facilitation (Bertness \& Callaway 1994; Bertness \& Yeh 1994; Greenlee \& Callaway 1996; Ibáñez \& Schupp 2001), and the general view that improvement of environmental conditions, notably reduction of water stress under nurse plants, are important aspects of facilitation in Mediterranean environments (Verdú \& García-Fayos 1996a; García et al. 2000; García-Fayos \& Gasque 2002; Castro et al. 2004; Gómez-Aparicio et al. 2004).

However, even with watering, the observed seedling density was higher than expected in open spaces. Coefficients of variation for seedling survival in open spaces were twofold higher than those from male or female trees. This indicates greater unpredictability of performance in open interspaces, and may explain the difference between expected and observed seedling density in this microhabitat. Nonetheless, expected and observed data for the rest of the microhabitats are very similar.

Herbivory is known to affect plant spatial distribu- tions (McAuliffe 1986; Ostfeld \& Canham 1993; García et al. 2000) but no significant effect of herbivory on seedling survival is found in our study. Even though livestock densities are high in the study area, naturally occurring seedlings are often seen. Other authors have found similar results for another Juniperus species (Jackson \& Van Auken 1997; although see Joy \& Young 2002) and suggest that unpalatability of junipers may restrict herbivory.

Adult population structure was aggregated at fine spatial scales, with peak aggregation at $4 \mathrm{~m}$. This distance coincides with tree canopy dimensions, under which seedling survival is enhanced. However, in the long termindividuals growing under parental trees may experience reduction of illumination and competition for water and other resources as growth limitations (Callaway 1995; Jackson \& Van Auken 1997; Verdú et al. 2004). Adult $J$. thurifera trees have been reported to be affected by competition (Pavón-García 2005). Thus, a turning point may occur in the life cycle of $J$. thurifera, at which life-stage conflicts weakens the strongly biased spatial pattern observed for seedlings, finally resulting in the slight aggregation observed for adult trees.

\section{Conclusions}

Both observational and experimental data show that the population structure of $J$. thurifera forests is shaped substantially by female trees, which attract dispersers, ameliorate environmental conditions and improve survival of young conspecifics. This accords with previous studies in which spatial discordance related to particular microhabitats has been attributed to effects of dispersal agents or improved environmental conditions (Jordano \& Herrera 1995; Schupp 1995; Clark et al. 1999; Rey \& Alcántara 2000; Traveset et al. 2003). However, life stages may or may not be coupled and most studies have found, to some degree, stage uncoupling or seed-seedling conflicts (Harper 1977; Herrera 1991; Schupp 1995; Rey \& Alcántara 2000; Traveset et al. 2003). Our study is, to our knowledge, the first study in which absence of seedseedling conflicts have been reported from Mediterranean habitats.

Facilitation seems to play a major role in regeneration of other Juniperus species in environments with limited water availability (see for instance Jackson \& Van Auken 1997). A model in which survival probability decreases away from parent plants was proposed by McCanny (1985) as a variation of the basic Janzen-Connell model for parent-offspring relationships. Patterns that accord with the McCanny model have rarely been observed, but our data conforms to this model. Such a pattern may be quite common in semi-arid environments in which 
survival is strongly determined by water availability, and notably for species narrowly adapted to particular microhabitats (Turkington 1979; Montesinos et al. 2006).

Acknowledgements. We wish to thank Rune Økland, Ragan Callaway, Eugene Schupp and Alfonso Valiente-Banuet for their revision of the manuscript. Thanks also to the inhabitants of the mountains for their hospitality: "Gracias a todos los habitantes de la Puebla de San Miguel, a su Alcalde, Luis María Alcusa, a Jesus Monedero, de la Guardería Forestal y a la brigada de IMELSA, especialmente a Paco, por su ayuda y atenciones durante la realización de este trabajo. Gracias también a Emilio Laguna, Amparo Olivares, Vicente del Toro, Paco, y el resto de la Brigada de las Microrreservas de Flora por su ayuda con las vallas de exclusión del ganado". Thanks for their help and support to the Llavoratori: Tono Bellido, Jorge Sellés, Gabriela Gleiser, Jaume Tormo and Esther Bochet. This work was funded by the Spanish Ministerio de Educación y Ciencia (AGL2001-1061). Daniel Montesinos enjoyed a grant (BES-2002-1828) from the MEC.

\section{References}

Alcántara, J.M., Rey, P.J., Sánchez-Lafuente, A.M. \& Valera, F. 2000. Early effects of rodent post-dispersal seed predation on the outcome of the plant-seed disperser interaction. Oikos 88: 362-370.

Bertaudière, V., Montes, N., Gauquelin, T. \& Edouard, J.L. 1999. Dendroecology of thuriferous juniper (Juniperus thurifera L.): example from a French Pyrenean site at Rie mountain. Ann. For. Sci. 56: 685-697.

Bertness, M.D. \& Callaway, R.M. 1994. Positive interactions in communities. Trends Ecol. Evol. 9: 191-193.

Bertness, M.D. \& Yeh, S.L. 1994. Cooperative and comptetitive interactions in the recruitment of marsh elders. Ecology 75: 2416-2429.

Callaway, R.M. 1995. Positive interactions among plants. Bot. Rev. 61: 306-349.

Callaway, R.M. 1998. Are positive interactions species-specific? Oikos 82: 202-207.

Callaway, R.M., Nadkami, N.M. \& Mahall, B.E. 1991. Facilitating and interfering effects of Quercus douglasii in central California. Ecology 72: 1484-1499.

Callaway, R.M., Brooker, R.W., Choler, P., Kikvidze, Z., Lortie, C.J., Michalet, R., Paolini, L., Pugnaire, F.I., Newingham, B., Aschehoug, E.T., Armas, C., Kikodze, D. \& Cook, B.J. 2002. Positive interactions among alpine plants increase with stress. Nature 417: 844-848.

Callaway, R.M., Pennings, S.C. \& Richards, C.L. 2003. Phenotypic plasticity and interactions among plants. Ecology 84: 1115-1128.

Calviño-Cancela, M. 2002. Spatial patterns of seed dispersal and seedling recruitment in Corema album (Empetraceae): the importance of unspecialized dispersers for regeneration. J. Ecol. 90: 775-784.

Castro, J., Zamora, R., Hodar, J.A., Gómez, J.M. \& GómezAparicio, L. 2004. Benefits of using shrubs as nurse plants for reforestation in Mediterranean mountains: A 4-year study. Restor. Ecol. 12: 352-358.

Castroviejo, S., Laínz, M., López González, G., Montserrat, P., Muñoz Garmendia, F., Paiva, J. \& Villar, L. 1986. Flora Iberica. Real Jardín Botánico, C.S.I.C., Madrid.

Ceballos, L. \& Ruiz de la Torre, J. 1979. Árboles y arbustos de la España peninsular. E.T.S.I. de Montes, Madrid, ES.

Clark, J.S., Beckage, B., Camill, P., Cleveland, B., HilleRisLambers, J., Lighter, J., McLachlan, J., Mohan, J. \& Wyckoff, P. 1999. Interpreting recruitment limitation in forests. Am. J. Bot. 86: 1-16.

Diaz, M. 1994. Granivory in cereal crop landscapes of central Spain: environmental correlates of the foraging impact of rodents, birds, and ants. Acta Oecol. 45: 739-751.

García, D. \& Obeso, J.R. 2003. Facilitation by herbivoremediated nurse plants in a threatened tree, Taxus baccata: local effects and landscape level consistency. Ecography 26: 739-750.

García, D. \& Ortiz-Pulido, R. 2004. Patterns of resource tracking by avian frugivores at multiple spatial scales: two case studies on discordance among scales. Ecography 27: 187-196.

García, D., Zamora, R., Hodar, J.A., Gómez, J.M. \& Castro, J. 2000. Yew (Taxus baccata L.) regeneration is facilitated by fleshy-fruited shrubs in Mediterranean environments. Biol. Conserv. 95: 31-38.

García-Fayos, P. \& Gasque, M. 2002. Consequences of a severe drought on spatial patterns of woody plants in a two-phase mosaic steppe of Stipa tenacissima L. J. Arid Environ. 52: 199-208.

García-Fayos, P. \& Verdú, M. 1998. Soil seed bank, factors controlling germination and establishment of a Mediterranean shrub: Pistacia lentiscus L. Acta Oecol. 19: 357-366.

Gómez-Aparicio, L., Zamora, R., Gómez, J.M., Hodar, J.A., Castro, J. \& Baraza, E. 2004. Applying plant facilitation to forest restoration: A meta-analysis of the use of shrubs as nurse plants. Ecol. Appl. 14: 1128-1138.

Greenlee, J. \& Callaway, R.M. 1996. Effects of abiotic stress on the relative importance of interference and facilitation. Am. Nat. 148: 386-396.

Gulías, J., Traveset, A., Riera, N. \& Mus, M. 2004. Critical stages in the recruitment process of Rhamnus alaternus $\mathrm{L}$. Ann. Bot. 93: 723-731.

Hampe, A. 2004. Extensive hydrochory uncouples spatiotemporal patterns of seedfall and seedling recruitment in a 'bird-dispersed' riparian tree. J. Ecol. 92: 797-807.

Hansson, L. 1985. The food of bank voles, wood mice and yellow-necked mice. Symp. Zool. Soc. Lond. 55: 141-168.

Harper, J.L. 1977. The population biology of plants. Academic Press, New York, NY, US.

Herrera, C.M. 1988. Habitat shaping, host plant use by a hemiparasitic shrub, and the importance of gut fellows. Oikos 51: 383-386.

Herrera, C.M. 1991. Dissecting factors responsible for individual variation in plant fecundity. Ecology 72: 1436-1448.

Herrera, C.M., Jordano, P., López-Soria, L. \& Amat, J. 1994. Recruitment of a mast fruiting, bird dispersed tree: bridging frugivore ativity and seedling establishment. Ecol. Monogr. 64: 315-344.

Hollander, J.L. \& Vander Wall, S.B. 2004. Effectiveness of six species of rodents as dispersers of singleleaf pinon pine (Pinus monophylla). Oecologia 138: 57-65. 
Holthuijzen, A.M.A. \& Sharik, T.L. 1985. Colonization of abandoned pastures by eastern red cedar (Juniperus virginiana L.). Can.J. For. Res. 15: 1065-1068.

Hulme, P.E. 1997. Post-dispersal seed predation and the establishment of vertebrate dispersed plants in Mediterranean scrublands. Oecologia 111: 91-98.

Ibáñez, I. \& Schupp, E.W. 2001. Positive and negative interactions between environmental conditions affecting Cercocarpus ledifolius seedling survival. Oecologia 129: 543-550.

Ihaka, R. \& Gentleman, R. 1996. R: A language for data analysis and graphics. J. Comput. Graph. Stat. 5: 299-314.

Jackson, J.T. \& Van Auken, O.W. 1997. Seedling survival, growth and mortality of Juniperus ashei (Cupressaceae) in the Edwards Plateau region of Central Texas. Tex. J. Sci. 49: 267-278.

Jordano, P. 1993. Geographical ecology and veriation of plantseed disperser interactions: southern Spanish junipers and frugivorous thrushes. Vegetatio 107/108: 87-104.

Jordano, P. \& Herrera, C.M. 1995. Shuffling the offspring: Uncoupling and spatial discordance of multiple stages in vertebrate seed dispersal. Ecoscience 2: 230-237.

Joy, D.A. \& Young, D.R. 2002. Promotion of mid-successional seedling recruitment and establishment by Juniperus virginiana in a coastal environment. Plant Ecology 160: 125-135.

Lasanta, T. 1996. El proceso de marginación de tierras en España. In: Lasanta, T. \& García-Ruiz, J.M. (eds.) Erosión y recuperación de tierras en áreas marginales, pp. 7-32. Instituto de Estudios Riojanos \& Sociedad Española de Geomorfología, Logroño, ES.

McAuliffe, J.R. 1986. Herbivore-limited establishment of a Sonoran Desert Tree, Cercidium microphyllum. Ecology 67: 276-280.

McCanny, S.J. 1985. Alternatives in parent-offspring relationships in plants. Oikos 45: 148-149.

McCullagh, P. \& Nelder, J.A. 1989. Generalized linear models. London, UK.

Melero, J.P. \& García-Fayos, P. 2001. Protocolos de germinación de semillas de sabina albar (Juniperus thurifera) y sabina rastrera (J. sabina). III Congreso Forestal Español. Montes para la sociedad del nuevo milenio. S.E.C.F., Granada, ES.

Montesinos, D., Mateu, I. \& García-Fayos, P. 2006. Conflicting selective forces underlying seed dispersal in the endangered plant Silene diclinis. Int. J. Plant. Sci. 167: 103-110.

Nanami, S., Kawaguchi, H. \& Yamakura, T. 1999. Dioecy-induced spatial patterns of two codominant tree species, Podocarpus nagi and Neolitsea aciculata. J. Ecol. 87: 678-687.

Nathan, R. \& Muller-Landau H.C. 2000. Spatial patterns of seed dispersal, their determinants and consequences for recruitment. Trends Ecol. Evol. 15: 278-285.

Norusis, M.J. 2002. SPSS 11.0: guide to data analysis. Prentice Hall, Upper Saddle River, NJ, US.

Orozco Bayo, E. 1999. Estudio de la capacidad regenerativa de los sabinares albares (Juniperus thurifera L.) occidentales de la provincia de Albacete. Universidad Politécnica de Madrid, Madrid, ES.

Ostfeld, R.S. \& Canham, C.D. 1993. Effects of meadow vole population-density on tree seedling survival in old fields. Ecology 74: 1792-1801.

Page, A.L. 1982. Chemical and microbiological properties. Methods for soil analysis. Madison, WI, US.

Pavón-García, J. 2005. Biología vegetativa y reproductiva en los primeros estadios de crecimiento de Juniperus thurifera $\mathrm{L}$. Ph.D. Thesis, Universidad de Alcalá, ES.

Rey, P.J. \& Alcántara, J.M. 2000. Recruitment dynamics of a fleshy-fruited plant (Olea europaea): connecting patterns of seed dispersal to seedling establishment. J. Ecol. 88: 622-633.

Rey, P.J., Garrido, J.L., Alcántara, J.M., Ramírez, J.M., Aguilera, A., García, L., Manzaneda, A.J. \& Fernández, R. 2002. Spatial variation in ant and rodent post-dispersal predation of vertebrate-dispersed seeds. Funct. Ecol. 16: 773-781.

Rodrigo, C. 1999. Puebla de San Miguel. Ayuntamiento de Puebla de San Miguel, Valencia, ES.

Rotundo, J.L. \& Aguiar, M.R. 2005. Litter effects on plant regeneration in arid lands: a complex balance between seed retention, seed longevity and soil-seed contact. J. Ecol. 93: 829-838.

Santos, T. \& Tellería, J.L. 1991. An experiment to test the consumption of arboreal food by wood mouse Apodemus sylvaticus. Z. Säugetierkunde 56: 19-24.

Santos, T. \& Tellería, J.L. 1994. Influence of forest fragmentation on seed consumption and dispersal of Spanish Juniper Juniperus thurifera. Biol. Conserv. 70: 129-134.

Santos, T., Tellería, J.L. \& Virgós, E. 1999. Dispersal of Spanish juniper Juniperus thurifera by birds and mammals in a fragmented landscape. Ecography 22: 193-204.

Schupp, E.W. 1995. Seed-seedling conflicts, habitat choice, and patterns of plant recruitment. Am. J. Bot. 82: 399-409.

Tomita, M., Hirabuki, Y. \& Seiwa, K. 2002. Post-dispersal changes in the spatial distribution of Fagus crenata seeds. Ecology 83: 1560-1565.

Traveset, A., Gulias, J., Riera, N. \& Mus, M. 2003. Transition probabilities from pollination to establishment in a rare dioecious shrub species (Rhamnus ludovici-salvatoris) in two habitats. J. Ecol. 91: 427-437.

Turkington, R. 1979. Neighbour relationships in grass-legume communities. IV. Fine scale biotic differentiation. Can. J. Bot. 57: 2711-2716.

Verdú, M. \& García-Fayos, P. 1996a. Nucleation processes in a Mediterranean bird-dispersed plant. Funct. Ecol. 10: 275280.

Verdú, M. \& García-Fayos, P. 1996b. Postdispersal seed predation in a Mediterranean patchy landscape. Acta Oecol. 17: 379-391.

Verdú, M. \& García-Fayos, P. 2003. Frugivorous birds mediate sex-biased facilitation in a dioecious nurse plant. J. Veg. Sci. 14: $35-42$.

Verdú, M., Villar-Salvador, P. \& García-Fayos, P. 2004. Gender effects on the post-facilitation performance of two dioecious Juniperus species. Funct. Ecol. 18: 87-93.

Zamora, R. 1990. The fruit diet of ring-ouzels (Turdus torquatus) wintering in the Sierra Nevada (South-East Spain). Alauda 58: 67-70.

Zar, J.H. 1996. Biostatistical analysis. 3rd ed. Prentice-Hall, Inc., Upper Saddle River, NJ, US.

Received 7 June 2006; Accepted 11 November 2006; Co-ordinating Editor: R.H. Økland. 